\title{
Rickettsia spp. in bats of Romania: high prevalence of Rickettsia monacensis in two insectivorous bat species
}

\author{
Ioana A. Matei ${ }^{1{ }^{*+}}$ (D) Alexandra Corduneanu ${ }^{2+}$, Attila D. Sándor ${ }^{2,3}$, Angela Monica Ionică ${ }^{2,4}$, Luciana Panait ${ }^{2}$, \\ Zsuzsa Kalmár ${ }^{2}$, Talida Ivan ${ }^{5}$, Ionel Papuc ${ }^{5}$, Cosmina Bouari ${ }^{1}$, Nicodim Fit ${ }^{1}$ and Andrei Daniel Mihalca ${ }^{2}$
}

\begin{abstract}
Background: Spotted fever group rickettsiae represent one of the most diverse groups of vector-borne bacteria, with several human pathogenic species showing an emerging trend worldwide. Most species are vectored by ticks (Ixodidae), with many zoonotic reservoir species among most terrestrial vertebrate groups. While the reservoir competence of many different vertebrate species is well known (e.g. birds, rodents and dogs), studies on insectivorous bats have been rarely performed despite their high species diversity, ubiquitous urban presence and importance in harboring zoonotic disease agents. Romania has a high diversity and ubiquity of bats. Moreover, seven out of eight SFG rickettsiae species with zoonotic potential were previously reported in Romania. Based on this, the aim of this study was to detect Rickettsia species in tissue samples in bats.
\end{abstract}

Methods: Here we report a large-scale study (322 bats belonging to 20 species) on the presence of Rickettsia spp. in Romanian bat species. Tissue samples from insectivorous bats were tested for the presence of Rickettsia DNA using PCR detection amplifying a $381 \mathrm{bp}$ fragment of the gltA gene. Positive results were sequenced to confirm the results. The obtained results were statistically analyzed by chi-squared independence test.

\footnotetext{
*Correspondence: ioana.matei@usamvcluj.ro

${ }^{\dagger}$ Ioana A. Matei and Alexandra Corduneanu contributed equally to this work

${ }^{1}$ Department of Microbiology, Immunology and Epidemiology, Faculty of Veterinary Medicine, University of Agricultural Sciences and Veterinary Medicine Cluj-Napoca, Cluj-Napoca, Romania

Full list of author information is available at the end of the article
}

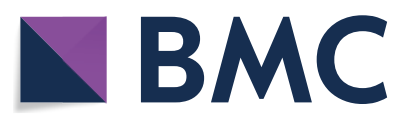

(c) The Author(s) 2021. This article is licensed under a Creative Commons Attribution 4.0 International License, which permits use, sharing, adaptation, distribution and reproduction in any medium or format, as long as you give appropriate credit to the original author(s) and the source, provide a link to the Creative Commons licence, and indicate if changes were made. The images or other third party material in this article are included in the article's Creative Commons licence, unless indicated otherwise in a credit line to the material. If material is not included in the article's Creative Commons licence and your intended use is not permitted by statutory regulation or exceeds the permitted use, you will need to obtain permission directly from the copyright holder. To view a copy of this licence, visit http://creativeco mmons.org/licenses/by/4.0/. The Creative Commons Public Domain Dedication waiver (http://creativecommons.org/publicdomain/ zero/1.0/) applies to the data made available in this article, unless otherwise stated in a credit line to the data. 
Results: Positive results were obtained in $14.6 \%$ of bat samples. Sequence analysis confirmed the presence of $R$. monacensis in two bat species (Nyctalus noctula and Pipistrellus pipistrellus) in two locations.

Conclusion: This study provides the first evidence of a possible involvement of these bat species in the epidemiol-
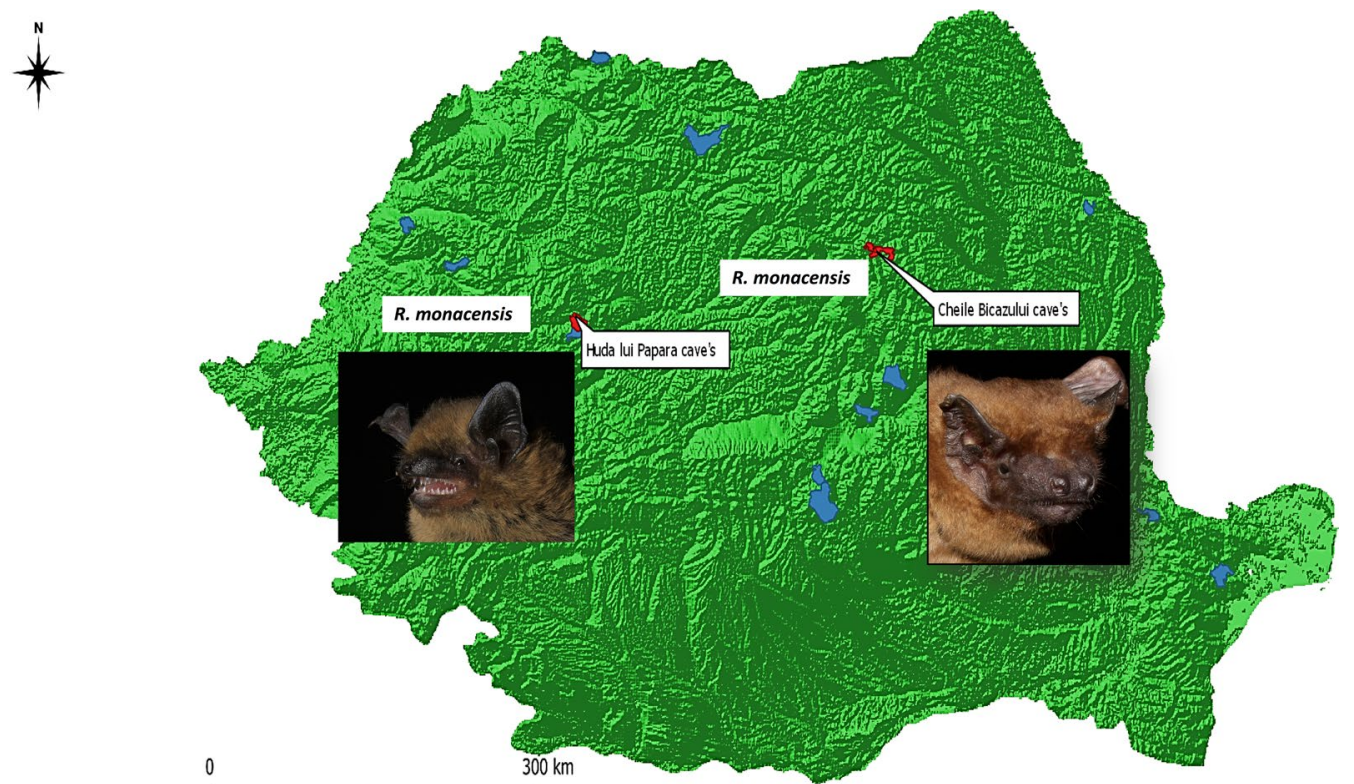

ogy of Rickettsia spp., highlighting the importance of bats in natural cycles of these vector-borne pathogens.

Keywords: Chiroptera, Insectivorous bats, SFG rickettsiae, Vector-borne diseases, Zoonotic reservoir

\section{Background}

Among tick-borne diseases, rickettsioses are considered to be the oldest known affecting humanity. Tick-borne rickettsioses are caused by obligate intracellular bacteria belonging to the spotted fever group (SFG) of the genus Rickettsia, one of the most diverse groups among Rickettsiales, comprising a large number of zoonotic agents [1]. The first clinical description of the prototypical tick-borne rickettsiosis (Rocky Mountain spotted fever, RMSF) was made in 1899 by Edward E. Maxey [2]. Its agent, Rickettsia rickettsii, was demonstrated to have vectorial transmission in 1906 by Howard T. Ricketts [3], which was later confirmed by S. Burt Wolbach [4].

This complex of diseases is still intensively studied, and newly associated clinical conditions are continuously described. Its importance and recognition have increased considerably over the last 3 decades [1]. More than 24 Rickettsia species and subspecies are associated with human infections, while for many others the public health relevance is still unknown [1]. In Europe, eight tick-borne rickettsiae with known pathogenicity to humans were reported in European patients: $R$. aeschlimannii, $R$. conorii subsp. conorii, $R$. helvetica, $R$. massiliae, $R$. monacensis, $R$. raoultii, $R$. sibirica subsp. mongolitimonae, and R. slovaca. Additionally, 15
Candidatus Rickettsia species and strains of unknown pathogenicity were also described [1]. Seven of the eight human pathogenic species were previously reported in Romania (Table 1) [5-15]. Despite the common detection of tick-borne rickettsiae in ticks collected from diverse hosts, to the best of our knowledge, they have been reported only in humans and birds in Romania.

Romania has a remarkable biodiversity, having in its territory 21 ecoregions in 5 biogeographical regions [16]. This unique situation is associated with a wide range of habitats and is mirrored by a very rich fauna including 32 species of insectivorous bats [17], more than $82 \%$ of all continental European bat species [18]. Romania is not only diverse in species, but also hosts large bat populations, including two of the largest hibernating colonies of bats from Europe ( $>100,000$ individuals) [19].

Bats are well-known reservoir hosts for important zoonotic viruses such as Lyssavirus and Ebola virus, probable reservoirs for Hendra and Nipah henipaviruses, MERS and SARS coronaviruses, probably including SARS-CoV-2, and other emerging viruses [20, 21]. Alongside viruses, in the last few years, bacterial and protozoan pathogens from bats have been intensively studied to clarify their zoonotic potential. As a result, several pathogens have been identified in different samples (blood, 
Table 1 Review of SFG Rickettsia detected in Romania

\begin{tabular}{|c|c|c|c|}
\hline Rickettsia species & Organism & Ticks origin & References \\
\hline R. aeschlimannii & Hyalomma marginatum & Cattle & [5] \\
\hline \multirow[t]{2}{*}{ R. conorii } & humans & - & {$[6,7]$} \\
\hline & Rhipicephalus sanguineus & Dog & {$[8]$} \\
\hline \multirow[t]{6}{*}{ R. helvetica } & Ixodes ricinus & Questing & [9] \\
\hline & I. ricinus & Dogs, cattle, horses & {$[8,10,11]$} \\
\hline & I. ricinus & Humans & {$[12]$} \\
\hline & I. ricinus & $\begin{array}{l}\text { Erithacus rubecula, Panurus biarmicus, Turdus } \\
\text { merula }\end{array}$ & [13] \\
\hline & $\begin{array}{l}\text { 1. arboricola } \\
\text { 1. redikorzevi }\end{array}$ & Birds* & [13] \\
\hline & $\begin{array}{l}\text { I. ricinus } \\
\text { I. crenulatus } \\
\text { Dermacentor reticulatus } \\
\text { R. sanguineus }\end{array}$ & Dogs, foxes, sheep, cats & {$[5]^{* *}$} \\
\hline \multirow[t]{3}{*}{ R. massiliae } & humans & - & [14] \\
\hline & $\begin{array}{l}\text { I. ricinus } \\
\text { I. arboricola }\end{array}$ & T.philomelos & [13] \\
\hline & D. reticulatus & Dogs, foxes & {$[5]$} \\
\hline \multirow[t]{6}{*}{ R. monacensis } & I. ricinus & Questing & {$[9]$} \\
\hline & I. ricinus & E. rubecula, T. merula & [13] \\
\hline & I. ricinus & Dogs, cattle, horses & {$[8,10]$} \\
\hline & I. ricinus & Humans & {$[12]$} \\
\hline & Haemaphysalis concinna & Birds* & {$[13]$} \\
\hline & $\begin{array}{l}\text { I. ricinus } \\
\text { D. reticulatus } \\
\text { R. sanguineus }\end{array}$ & Dogs, foxes, cats & {$[5]^{* *}$} \\
\hline \multirow[t]{5}{*}{ R. raoultii } & humans & - & [14] \\
\hline & D. reticulatus & Questing & {$[5,9]$} \\
\hline & D. reticulatus & Dogs & {$[8]$} \\
\hline & D. marginatus & Cattle & [10] \\
\hline & $\begin{array}{l}\text { D. reticulatus } \\
\text { D. marginatus } \\
\text { R. sanguineus }\end{array}$ & Dogs, sheep, goats & {$[5]^{* *}$} \\
\hline \multirow[t]{5}{*}{ R. slovaca } & humans & - & [14] \\
\hline & D. marginatus & Cattle, sheep & {$[10]$} \\
\hline & D. reticulatus & Dogs & [8] \\
\hline & I. ricinus & T. merula & [13] \\
\hline & $\begin{array}{l}\text { I. ricinus } \\
\text { D. marginatus } \\
\text { R. sanguineus }\end{array}$ & Dogs, foxes, sheep, goats & {$[5]^{* *}$} \\
\hline
\end{tabular}

*The bird species is not specified

**Which tick species was collected from which host is not clearly specified

tissues, ectoparasites, guano) such as Babesia spp. [22, 23], different strains of Bartonella spp. [24, 25], including species with zoonotic potential [26], Borrelia spp., some with a possible zoonotic potential [27, 28], and Rickettsia spp. [29, 30].

Bats are hosts for their specific ectoparasites such as bat bugs, flies, fleas, mites and ticks (hard and soft). In Europe, three species of hard ticks (Ixodes ariadnae, I. simplex and I. vespertilionis) and two species of soft tick (Argas vespertilionis and A. transgariepinus) are considered specific to bats [17]. However, other generalist tick species have been occasionally found on bats, including SFG-rickettsiae-vector ticks, such as I. ricinus and Haemaphysalis concinna [1, 17, 29], suggesting the possibility of harboring these pathogens.

Motivated by the high diversity and ubiquity of bats in Romania and their potential to harbor SFG rickettsiae, 
the aim of this study was to detect Rickettsia species in tissue samples in bats.

\section{Methods \\ Tissue collection}

The samples were collected from carcasses of bats accidentally killed, mainly by collisions $(n=165)$, or which died of natural causes $(n=157)$. The collection of carcasses was performed during all-year periods between 2011-2019. The majority of naturally caused deaths were recorded in the late spring. Bats were identified to the species level using morphological keys [31]. Some of the carcasses are found in the Grigore Antipa National Museum of Natural History in Bucharest. The carcasses were kept individually in plastic bags and deep frozen ($20{ }^{\circ} \mathrm{C}$ ) until analysis. A total of 322 bat samples belonging to 20 species (Additional file 1: Table S1) originating from 13 locations in Romania were necropsied. The heart tissue was used for DNA extraction, as this was the only tissue available from all the animals because of carcass damage (smashed, old, partially eaten, etc.). No individual animal was harmed or killed for the purpose of this study.

\section{DNA extraction}

Genomic DNA was extracted from each tissue sample using commercial kits (ISOLATE II Genomic DNA Kit, Bioline, UK), following the manufacturer's instructions. To assess cross-contamination between extracts, negative controls consisting only of reaction mixes were used. The DNA quantity and purity were assessed on a Nanodrop ND-1000 spectrophotometer analyzer (NanoDrop Technologies, Inc., Wilmington, DE, USA), using a representative number of randomly selected samples.

\section{Polymerase chain reaction (PCR) and agarose gel electrophoresis}

The samples were assessed for the presence of SFG rickettsiae using a group-specific set of primers amplifying a 381 bp fragment of the rickettsial gltA gene (Rsfg877: GGGGGCCTGCTCACGGCGG; Rsfg1258: ATTGCA AAAAGTACAGTGAACA) [32]. The amplification was carried out in $25 \mu \mathrm{l}$ reaction mixture containing $12.5 \mu \mathrm{l}$ of Green PCR Master Mix (Rovalab GmBH), $6.5 \mu \mathrm{l} \mathrm{PCR}$ water, $1 \mu \mathrm{l}$ of each primer $(0.01 \mathrm{mM})$ and a $4 \mu \mathrm{l}$ aliquot of isolated DNA. The amplification profile consisted of 5 min of initial denaturation at $95^{\circ} \mathrm{C}$, followed by 35 cycles of denaturation at $95{ }^{\circ} \mathrm{C}$ for $30 \mathrm{~s}$, annealing at $53{ }^{\circ} \mathrm{C}$ for $30 \mathrm{~s}$ and extension at $72{ }^{\circ} \mathrm{C}$ for $30 \mathrm{~s}$ and a final extension at $72{ }^{\circ} \mathrm{C}$ for $5 \mathrm{~min}$. In each PCR reaction set, positive and negative controls were included. Positive controls consisted of DNA extracted from Ixodes ricinus collected from a bird infected with $R$. helvetica, previously confirmed by sequencing (accession no. KR906075). The negative control consisted of reaction mix without DNA. The PCR was carried out using a $\mathrm{T} 100^{\mathrm{TM}}$ Thermal Cycler (Bio-Rad). PCR products were visualized by electrophoresis in a $1.5 \%$ agarose gel stained with $\mathrm{SYBR}^{\circledR}$ Safe DNA gel stain (Invitrogen).

\section{DNA sequencing}

All positive PCR products were purified using Isolate II PCR and Gel Kit (Bioline). Sequencing analysis was performed (Macrogen Europe, Amsterdam), and the obtained sequences were edited and analyzed using Geneious $^{\circledR}$ (Biomatters LTD) 4.8.7 and compared with those available in the GenBank database by BLASTn analysis (http://blast.ncbi.nlm.nih.gov/Blast.cgi).

\section{Statistical analysis}

The prevalence of Rickettsia spp. infection was calculated using Epi Info ${ }^{\mathrm{TM}} 7$ (CDC, USA) software with a 95\% confidence interval. To evaluate differences in prevalence between localities and bat species, a chi-square test of independence was applied, and a $p$-value $<0.05$ was considered significant.

\section{Results}

SFG rickettsiae DNA was detected in $14.6 \%(n=47 / 322$, 95\%CI: 11.02-19.04) of samples. Positive samples were detected in Nyctalus noctula (22 out of 188 tested), Pipistrellus pipistrellus (13 out of 55 tested), Myotis alcathoe (5 out of 12 tested), P. nathusii (4 out of 25 tested), Plecotus auritus ( 1 out of 6 tested), Vespertilio murinus (1 out of 4 tested) and P. pygmaeus ( 1 out of 2 tested) from five different locations (Table 2). The prevalence of Rickettsia spp. was $23.64 \%$ (95\%CI: 13.23-37.02) in P. pipistrellus and 11.7\% (95\%CI: 7.48-17.18) in N. noctula. For the remaining species, Rickettsia spp. prevalence was not considered because of the small number of individuals tested.

Among the 47 positive samples, only 17 were suitable for sequencing (> $30 \mathrm{ng} / \mu \mathrm{l}$ DNA concentration). The sequences analysis showed $99.7 \%$ to $100 \%$ identity with $R$. monacensis found in I. ricinus from different geographical origins such as: Romania, Italy or Serbia (accession no. JX003686; GQ925822; KY203388). Four obtained sequences of gltA fragments (MT741493-MT741496) were deposited in the GenBank database. The short length of the sequences allowed the confirmation of the Rickettsia species, but they were inappropriate for further testing of strain genetic variability.

Following sequence analysis, $R$. monacensis presence was confirmed in all 17 sequences of bat samples, in $5 P$. pipistrellus (accession no. MT741493-MT741494) and in 12 N. noctula (accession no. MT741495-MT741496). 


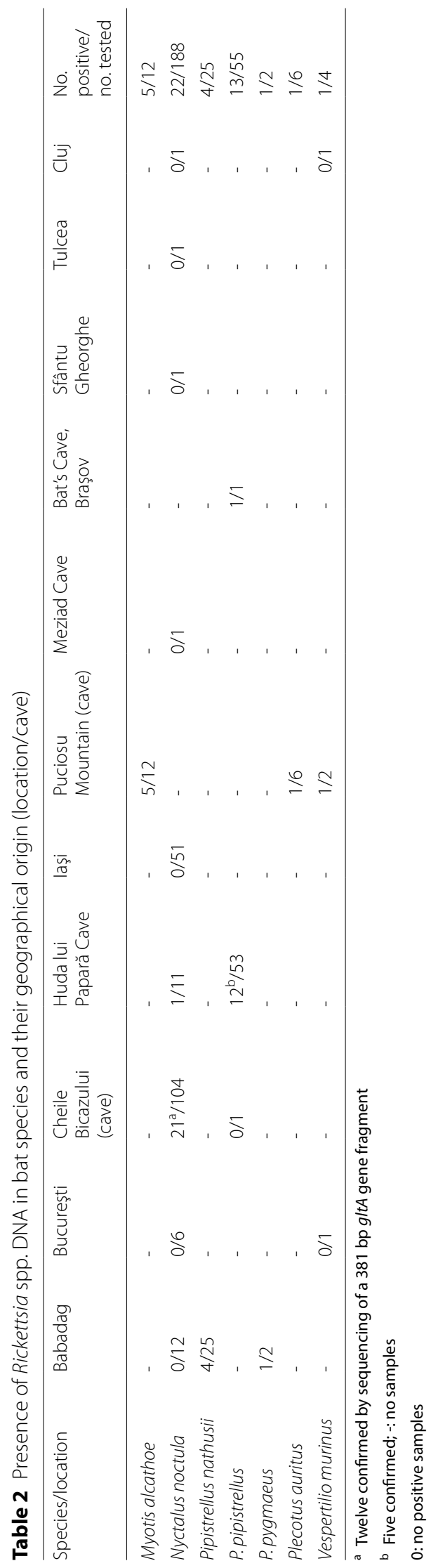


Table 3 Rickettsia spp. (SFG and RFG and related species) in bat specialist ectoparasites (soft ticks and other, specified in brackets)

\begin{tabular}{|c|c|c|c|c|}
\hline Species & Host & Origin & Country & Ref. \\
\hline Candidatus'Rickettsia andeanae' & Trichobius joblingi (fly) & Carollia perspicillata & Brazil & {$[33]$} \\
\hline $\begin{array}{l}\text { Candidatus 'Rickettsia nicoyana' -related to Candidatus 'Rickettsia } \\
\text { wissemanii' and R. peacockii }\end{array}$ & O. knoxjonesi & B. plicata & Costa Rica & {$[34]$} \\
\hline Candidatus'Rickettsia wissemanii'_-related to R. peacockii & O. hasei & Noctilio albiventris & French Guiana & {$[35]$} \\
\hline Candidatus 'Rickettsia wissemanii' & O. hasei & Eptesicus diminutus & Argentina & {$[36]$} \\
\hline Candidatus'Rickettsia wissemanii' & O. hasei & Artibeus planirostris & Brazil & {$[37]$} \\
\hline R. africae-like sequences & A. vespertilionis & M. dasycneme & Hungary & {$[38]$} \\
\hline R. helvetica & A. vespertilionis & V.murinus & China & {$[38]$} \\
\hline R. helvetica & Nicteridopsylla eusaeca (fly) & N. noctula & Hungary & {$[39]$} \\
\hline R. hoogstraalii & A. transgariepinus & P. hesperidus & South Africa & {$[38]$} \\
\hline R. lusitaniae & O. yumatensis & Caves walls & Mexico & {$[40]$} \\
\hline R. lusitaniae & Ornithodoros spp. & Balantiopteryx plicata & Mexico & {$[38]$} \\
\hline R. lusitaniae & A. vespertilionis & V.murinus & China & {$[38]$} \\
\hline Rickettsia spp. Av 22 related to AvBat & A. vespertilionis & Multiple bats species & Hungary & {$[38]$} \\
\hline Rickettsia spp. AvBat, related to Rickettsia sp. strain S and R. africae & A. vespertilionis & Home attic & France & {$[27]$} \\
\hline Rickettsia spp. related to $R$. honei-like strains & A. vespertilionis & Scotophilus kuhlii & Pakistan & {$[41]$} \\
\hline $\begin{array}{l}\text { Rickettsia spp. related to R. massiliae and Candidatus 'Rickettsia } \\
\text { barbariae' }\end{array}$ & Spinturnix myoti (mite) & M. myotis & Poland & [42] \\
\hline Rickettsia spp. related to R. peacockii and R. rickettsii & Carios (O.) kelleyi & buildings & lowa, USA & {$[43]^{*}$} \\
\hline Rickettsia spp. related to $R$. raoultii & $\begin{array}{l}\text { Eucampsipoda madagascarensis } \\
\text { (fly) Penicillidia leptothrinax } \\
\text { (fly) }\end{array}$ & Rousettus madagascariensis & Madagascar & {$[44]$} \\
\hline $\begin{array}{l}\text { Rickettsia spp. related to R. sibirica and R. conorii (17kDA 100\% } \\
\text { similar) }\end{array}$ & A. vespertilionis & $\begin{array}{l}\text { P. pipistrellus } \\
\text { P. auritus }\end{array}$ & England & {$[45]$} \\
\hline
\end{tabular}

* In this study it was also demonstrated that both trans-stadial and transovarial transmissions are possible

All the confirmed positive samples originated from two distinct locations (Table 2). Since in these two locations these two species represented almost half of the collected samples (104 out of $188 \mathrm{~N}$. noctula in Cheile Bicazului and 53 out of 55 P. pipistrellus from "Huda lui Papara" Cave, Additional file 1: Table S1), the differences in prevalence obtained for different locations or species were not significant.

\section{Discussion}

To the best of our knowledge, this study is the first report of SFG rickettsiae in bat tissue samples in Europe and the first report of $R$. monacensis in tissues of P. pipistrellus and N. noctula (insectivorous bats) worldwide. Although SFG rickettsiae were not previously detected in bat tissue samples in Europe, SFG rickettsiae and related Rickettsia species were detected in bat specialist ectoparasites in Europe as well in other parts of the world (Table 3) [33-45]. This may suggest bat's and/or their ectoparasites potential involvement in the transmission of these pathogens. This hypothesis is also sustained by the detection of SFG rickettsiae in bat tissue samples on other continents. For instance, in serological studies, antibodies against several Rickettsia spp. (R. amblyommii, R. conorii, $R$. parkeri, $R$. rickettsia and $R$. rhipicephali) were identified in bat samples collected from North and South America and from Asia [46-48]. Moreover, SFG Rickettsia spp. DNA was identified in blood or tissue samples from bats in Africa, America and Asia [49-51]. Different bat species (Miniopterus natalensis, Nycteris thebaica, Epomophorus wahlbergi, Scotophilus dinganii and Glauconycteris variegata) from South Africa were found positive for the presence of Rickettsia DNA, belonging to the SFG group, closely related to R. conorii [49]. In Saint Kitts, rickettsial DNA (99\% similar to $R$. africae $17 \mathrm{kD}$ protein gene) was detected in blood samples of Artibeus jamaicensis and Ardops nichollsi [50]. In China, R. parkeri, R. lusitaniae, $R$. slovaca and $R$. raoultii were detected in tissue samples collected from $P$. pisterellus [51]. In addition, $R$. raoultii and $R$. rickettsii were also detected in their ectoparasites (A. vespertilionis). Among these, four ticks positive for $R$. raoultii were removed from a $R$. raoultii-positive bat [49], suggesting the possible involvement of $A$. vespertilionis in the transmission of SFG rickettsiae among bats.

Rickettsia monacensis has a wide distribution, and has been detected all over Europe in its main vector, I. rici$n u s$ [reviewed by $1,52,53$ ]. The prevalence of $R$. monacensis in ticks varied between $0.5 \%$ in Germany and 
$57 \%$ in Italy [reviewed by 1,53 ]. Currently $R$. monacensis is considered a zoonotic species, causing MSF-like illness in humans $[54,55]$. Its presence in bat tissues observed in this study may suggest bats' involvement in Rickettsia spp. epidemiology also in Europe. Soft ticks collected from P. pipistrellus have already yielded five different Rickettsia spp. DNA (Rickettsia sp. AvBat [27], R. sibirica and R. conorii-[40], R. lusitaniae and Rickettsia africae-like-[38]), while fleas and feces collected from $N$. noctula tested positive for Rickettsia spp. in Hungary $[30,42]$. In addition, $R$. helvetica was previously detected in its vector (I. ricinus) tick collected from bats (Rhinolophus hipposideros and M. myotis) from Poland [29]. Thus, either these two bat species regularly harbor Rickettsia spp. infections or their associated ectoparasites (especially the soft tick, A. vespertilionis) may play a vectorial role in these bacteria. Argas vespertilionis commonly infests these bats and also is known to bite humans [56]. In addition, P. pipistrellus and $N$. noctula species are the most common bats in urbanized areas, with important populations roosting in anthropogenic roosts [31], altogether making them of interest in the study of vector-borne pathogen cycles and highlighting their importance as possible candidates for Rickettsia spp. reservoirs in urbanized habitats.

\section{Conclusions}

The detection of $R$. monacensis in the present study reconfirms the presence and circulation of this SFG rickettsiae in insectivorous bats. To the best of our knowledge, this study represents the first detection of $R$. monacensis in bat tissue samples in Europe and its first detection in P. pipistrellus and N. noctula bat species. Considering the zoonotic potential of $R$. monacensis, the detection of putative and also known vectors in bats and its detection in bat tissue samples, it is important to establish the importance of bats in the epidemiology of Rickettsia spp. in general, and R. monacensis in particular, by further research.

\section{Supplementary Information}

The online version contains supplementary material available at https://doi. org/10.1186/s13071-021-04592-x.

Additional file1: Table S1. Number of bat samples included in the study according to the species and geographical origin (location/cave) (DOCX $21 \mathrm{~KB})$

\section{Abbreviations}

Acc. no.: GeneBank accession number; DNA: Deoxyribonucleic acid; MSF: Mediterranean spotted fever; MERS: Middle East respiratory syndrome; PCR: Polymerase chain reaction; RFG: Rickettsia felis group; RMSF: Rocky Mountain
Spotted Fever; SARS: Severe Acute Respiratory Syndrome; SFG: Spotted Fever Group.

\section{Acknowledgements}

We acknowledge the help provided by L. Barti and I. Coroiu in the fieldwork.

\section{Authors' contributions}

IAM: study design, funding, sample collection, manuscript writing. AC: sample collection, PCR analysis, revision of the work. ADS: sample collection, funding, revision of the work. AMI: sample collection, sequences analysis. LP: sequence analysis. ZK: sample collection. TI: PCR analysis. IP: revision of the work. CB: revision of the work. NF: revision of the work. ADM: study design, funding, revision of the work. All authors read and approved the final manuscript.

\section{Funding}

This work was supported by the CNCS-UEFISCDI Grant Agency Romania, grant numbers PD34/2018, PD39/2020 and PCCDI 57/2018, and ADS was supported by the János Bolyai Research Scholarship of the Hungarian Academy of Science and the ÚNKP 19-4-ÁTE-10 New National Excellence Program of the MIT and NKFIH 132794.

\section{Availability of data and materials}

All data generated or analyzed during this study are included in this published article [and its supplementary information files].

Ethics approval and consent to participate

Not applicable.

Consent for publication

Not applicable.

\section{Competing interests}

The authors declare that they have no competing interests.

\section{Author details}

${ }^{1}$ Department of Microbiology, Immunology and Epidemiology, Faculty of Veterinary Medicine, University of Agricultural Sciences and Veterinary Medicine Cluj-Napoca, Cluj-Napoca, Romania. ${ }^{2}$ Department of Parasitology and Parasitic Diseases, Faculty of Veterinary Medicine, University of Agricultural Sciences and Veterinary Medicine Cluj-Napoca, Cluj-Napoca, Romania. ${ }^{3}$ Department of Parasitology and Zoology, University of Veterinary Medicine, Budapest, Hungary. ${ }^{4}$ Regele Mihai I al României" Life Science Institute, University of Agricultural Sciences and Veterinary Medicine Cluj-Napoca, Cluj-Napoca, Romania. ${ }^{5}$ Department of Semiology, Faculty of Veterinary Medicine, University of Agricultural Sciences and Veterinary Medicine, Cluj-Napoca, Romania.

Received: 4 September 2020 Accepted: 11 January 2021

Published online: 10 February 2021

\section{References}

1. Parola P, Paddock CD, Socolovschi C, Labruna MB, Mediannikov O, KernifT, et al. Update on tick-borne rickettsioses around the world: a geographic approach. Clin Microbiol Rev. 2013;26:657-702.

2. Maxey EE. Some observations of the so-called spotted fever of Idaho. Med Sentinel. 1899:10:433-8.

3. Ricketts HT. The transmission of Rocky Mountain Spotted Fever by the bite of the wood-tick (Dermacentor occidentalis). JAMA. 1906;47:358.

4. Wolbach SB. Studies on Rocky Mountain spotted fever. The J Med Res. 1919:41:1.

5. Andersson MO, Tolf C, Tamba P, Stefanache M, Radbea G, Frangoulidis D, et al. Molecular survey of neglected bacterial pathogens reveals an abundant diversity of species and genotypes in ticks collected from animal hosts across Romania. Parasit Vectors. 2018;11:144.

6. Pitigoi D, Olaru ID, Badescu D, Rafila A, Arama V, Hristea A. Mediterranean spotted fever in southeastern Romania. Bio Med Res Int. 2013. https://doi. org/10.1155/2013/395806.

7. Serban R, Pistol A, Neguț M, Cucuiu R. Rickettsia conorii infection in Romania, 2000-2008, Bacteriologia, virusologia, parazitologia, epidemiologia (Bucharest, Romania: 1990). 2009;54:177-83 
8. Ionita M, Silaghi C, Mitrea IL, Edouard S, Parola P, Pfister K. Molecular detection of Rickettsia conorii and other zoonotic spotted fever group rickettsiae in ticks Romania. Ticks Tick Borne Dis. 2016;7:150-3.

9. Raileanu C, Moutailler S, Porea D, Oslobanu L, Anita D, Anita A, et al. Molecular evidence of Rickettsia spp., Anaplasma phagocytophilum, and "Candidatus Neoehrlichia mikurensis" in ticks from natural and urban habitats in Eastern Romania. Vector Borne Zoonotic Dis. 2018:18:343-9.

10. Ionita M, Mitrea IL, Pfister K, Hamel D, Silaghi C. Molecular evidence for bacterial and protozoan pathogens in hard ticks from Romania. Vet Parasitol. 2013;196:71-6.

11. Andersson MO, Marga G, Banu T, Dobler G, Chitimia-Dobler L. Tick-borne pathogens in tick species infesting humans in Sibiu County, central Romania. Parasitol Res. 2018:117:1591-7.

12. Matei IA, Kalmár Z, Lupşe M, D'Amico G, lonică AM, Dumitrache MO, et al. The risk of exposure to rickettsial infections and human granulocytic anaplasmosis associated with Ixodes ricinus tick bites in humans in Romania: a multiannual study. Ticks Tick Borne Dis. 2017;8:375-8.

13. Mărcuțan ID, Kalmár Z, lonică AM, D'Amico G, Mihalca AD, Vasile C, et al. Spotted fever group rickettsiae in ticks of migratory birds in Romania. Parasit Vectors. 2016;9:294

14. Zaharia M, Popescu CP, Florescu SA, Ceausu E, Raoult D, Parola P, et al. Rickettsia massiliae infection and SENLAT syndrome in Romania. Ticks Tick Borne Dis. 2016;7:759-62.

15. Sándor AD, Kalmár Z, Matei I, lonică AM, Mărcuțan ID, et al. Urban breeding corvids as disseminators of ticks and emerging tick-borne pathogens. Vector-Borne Zoonotic Dis. 2017;17:152-4.

16. National Environment Protection Agency, Annual report 2018. http:// www.anpm.ro/raport-de-mediu. Accessed in 13 May 2020

17. Sándor AD, Corduneanu A, Péter Á, Mihalca AD, Barti L, Csősz I, et al. Bats and ticks: host selection and seasonality of bat-specialist ticks in eastern Europe. Parasit Vectors. 2019;12:1.

18. Russo D, Billington G, Bontadina F, Dekker J, Dietz M, Gazaryan S, et al. Identifying key research objectives to make European forests greener for bats. Front Ecol Evol. 2016;4:87.

19. Coroiu I. Bat fauna in caves of Romania. In: Ponta GML, Onac BP, editors. Cave and karst systems of Romania. Cham: Springer; 2019. p. 493-9.

20. Brook CE, Dobson AP. Bats as 'special' reservoirs for emerging zoonotic pathogens. Trends Microbiol. 2015;23:172-80.

21. Zhou P, Yang XL, Wang XG, Hu B, Zhang L, Zhang W, et al. A pneumonia outbreak associated with a new coronavirus of probable bat origin. Nature. 2020;579:270-3.

22. Hornok S, Szőke K, Kováts D, Estók P, Görföl T, Boldogh SA, et al. DNA of piroplasms of ruminants and dogs in ixodid bat ticks. PLoS ONE. 2016;11:e0167735.

23. Corduneanu A, Hrazdilová K, Sándor AD, Matei IA, lonică AM, Barti L, et al. Fuehrer, Babesia vesperuginis, a neglected piroplasmid: new host and geographical records, and phylogenetic relations. Parasit Vectors. 2017;11:598.

24. Corduneanu A, Sándor AD, lonică AM, Hornok S, Leitner N, Bagó Z, et al. Bartonella DNA in heart tissues of bats in central and eastern Europe and a review of phylogenetic relations of bat-associated bartonellae. Parasit Vector. 2018;11:598.

25. Urushadze L, Bai Y, Osikowicz L, McKee C, Sidamonidze K, Putkaradze D, et al. Prevalence, diversity, and host associations of Bartonella strains in bats from Georgia (Caucasus). PLoS Negl Trop Dis. 2017;11:e0005428.

26. Veikkolainen V, Vesterinen EJ, Lilley TM, Pulliainen AT. Bats as reservoir hosts of human bacterial pathogen, Bartonella mayotimonensis. Emerg Infect Dis. 2014:20:960.

27. Socolovschi C, Kernif T, Raoult D, Parola P. Borrelia, Rickettsia, and Ehrlichia species in bat ticks, France, 2010. Emerg Infect Dis. 2012;18:1966.

28. Qiu Y, Nakao R, Hang'ombe BM, Sato K, Kajihara M, Kanchela S, et al. Human borreliosis caused by a new world relapsing fever borrelia-like organism in the old world. Clin Infect Dis. 2019;69:107-12.

29. Piksa K, Stańczak J, Biernat B, Górz A, Nowak-Chmura M, Siuda K. Detection of Borrelia burgdorferi sensu lato and spotted fever group rickettsiae in hard ticks (Acari, Ixodidae) parasitizing bats in Poland. Parasitol Res. 2016;115:1727-31.

30. Hornok S, Szőke K, Estók P, Krawczyk A, Haarsma AJ, Kováts D, et al. Assessing bat droppings and predatory bird pellets for vector-borne bacteria: molecular evidence of bat-associated Neorickettsiasp. in Europe. Anton Leeuw. 2018;111:1707-17.
31. Dietz C, Von Helversen O, Nill D. Bats of Britain, Europe and northwest Africa. London: A\&C Black; 2009.

32. Regnery RL, Spruill CL, Plikaytis BD. Genotypic identification of rickettsiae and estimation of intraspecies sequence divergence for portions of two rickettsial genes. J Bacteriol. 1991;173:1576-89.

33. Do Amaral RB, Lourenco EC, Famadas KM, Garcia AB, Machado RZ, Andre MR. Molecular detection of Bartonella spp. and Rickettsia spp. in bat ectoparasites in Brazil. PLoS ONE. 2018;13:e0198629.

34. Moreira-Soto RD, Moreira-Soto A, Corrales-Aguilar E, Calderón-Arguedas Ó, Troyo A. 'Candidatus Rickettsia nicoyana': a novel Rickettsia species isolated from Ornithodoros knoxjonesi in Costa Rica. Ticks Tick Borne Dis. 2017;8:532-6.

35. Tahir D, Socolovschi C, Marié JL, Ganay G, Berenger JM, Bompar JM, et al. New Rickettsia species in soft ticks Ornithodoros hasei collected from bats in French Guiana. Ticks Tick Borne Dis. 2016;7:1089-96.

36. Colombo VC, Montani ME, Pavé R, Antoniazzi LR, Gamboa MD, Fasano AA et al. First detection of "Candidatus Rickettsia wissemanii" in Ornithodoros hasei (Schulze, 1935) (Acari: Argasidae) from Argentina. Ticks Tick Borne Dis. 2020;14:101442.

37. Luz HR, Muñoz-Leal S, de Carvalho WD, Castro IJ, Xavier BS, Toledo JJ, et al. Detection of "Candidatus Rickettsia wissemanii" in ticks parasitizing bats (Mammalia: Chiroptera) in the northern Brazilian Amazon. Parasitol Res. 2019;118:3185-9.

38. Hornok S, Szőke K, Meli ML, Sándor AD, Görföl T, Estók P, et al. Molecular detection of vector-borne bacteria in bat ticks (Acari: Ixodidae, Argasidae) from eight countries of the Old and New Worlds. Parasit Vectors. 2019;12:1-7.

39. Hornok S, Kovács R, Meli ML, Gönczi E, Hofmann-Lehmann R, Kontschan J, et al. First detection of bartonellae in a broad range of bat ectoparasites. Vet Microbiol. 2012;3:541-3.

40. Sánchez-Montes S, Guzmán-Cornejo C, Martínez-Nájera Y, Becker I, Venzal JM, Labruna MB. Rickettsia lusitaniae associated with Ornithodoros yumatensis (Acari: Argasidae) from two caves in Yucatan, Mexico. Ticks Tick Borne Dis. 2016;7:1097-101.

41. Ullah H, Kontschán J, Takács N, Wijnveld M, Schötta AM, Boldogh SA. A new Rickettsia honei-related genotype, two novel soft tick haplotypes and first records of three mite species associated with bats in Pakistan. Syst Appl Acarol. 2019:24:2106-18.

42. Szubert-Kruszyńska A, Stańczak J, Cieniuch S, Podsiadły E, Postawa T, Michalik J. Correction to: Bartonella and Rickettsia infections in haematophagous Spinturnix myoti Mites (Acari: Mesostigmata) and their bat host, Myotis myotis (Yangochiroptera: Vespertilionidae), from Poland. Microb Ecol. 2019;77:769.

43. Loftis AD, Gill JS, Schriefer ME, Levin ML, Eremeeva ME, Gilchrist MR, et al. Detection of Rickettsia, Borrelia, and Bartonella in Carios kelleyi (Acari: Argasidae). J Med Entomol. 2005;42:473-80.

44. Wilkinson DA, Duron O, Cordonin C, Gomard Y, Ramasindrazana B, Mavingui $P$, et al. The bacteriome of bat flies (Nycteribiidae) from the Malagasy region: a community shaped by host ecology, bacterial transmission mode, and host-vector specificity. Appl Environ Microbiol. 2016:82:1778-88.

45. LV J, de Marco MD, Goharriz H, Phipps LP, McElhinney LM, Hernández-Triana LM, et al. Detection of tick-borne bacteria and Babesia with zoonotic potential in Argas (Carios) vespertilionis (Latreille, 1802) ticks from British bats. Sci Rep. 2018;8:1-9.

46. Choi CS, Lee YT. Seroepidemiological survey of Rickettsia in rodents and bats. J Korean Soc Microbiol. 1996;31:367-72.

47. Reeves WK, Streicker DG, Loftis AD, Dasch GA. Serologic survey of Eptesicus fuscus from Georgia, USA for Rickettsia and Borrelia and laboratory transmission of a Rickettsia by bat ticks. J Vector Ecol. 2006;31:386-9.

48. D'Auria SR, Camargo MC, Pacheco RC, Savani ES, Dias MA, da Rosa AR, et al. Serologic survey for rickettsiosis in bats from São Paulo city, Brazil. Vector Borne Zoonotic Dis. 2010;10(5):459-63.

49. Dietrich M, Tjale MA, Weyer J, Kearney T, Seamark EC, Nel LH, et al. Diversity of Bartonella and Rickettsia spp. in bats and their bloodfeeding ectoparasites from South Africa and Swaziland. PLoS ONE. 2016;11:e0152077.

50. Reeves WK, Beck J, Orlova MV, Daly JL, Pippin K, Revan F, et al. Ecology of bats, their ectoparasites, and associated pathogens on Saint Kitts Island. J Med Entomol. 2016:53:1218-25. 
51. Zhao S, Yang M, Liu G, Hornok S, Zhao S, Sang C, et al. Rickettsiae in the common pipistrelle Pipistrellus pipistrellus (Chiroptera: Vespertilionidae) and the bat soft tick Argas vespertilionis (Ixodida: Argasidae). Parasit Vectors. 2020;13:1-6.

52. Oteo JA, Portillo A. Tick-borne rickettsioses in Europe. Ticks Tick Borne Dis. 2012;3:271-8.

53. Simser JA, Palmer AT, Fingerle V, Wilske B, Kurtti TJ, Munderloh UG Rickettsia monacensis sp. nov, a spotted fever group Rickettsia, from ticks (Ixodes ricinus) collected in a European city park. Appl Environ Microbiol. 2002;68:4559-66.

54. Jado I, Oteo JA, Aldámiz M, Gil H, Escudero R, Ibarra V, et al. Rickettsia monacensis and human disease, Spain. Emerg Infect Dis. 2007;13:1405.
55. Madeddu G, Mancini F, Caddeo A, Ciervo A, Babudieri S, Maida I, et al. Rickettsia monacensis as cause of Mediterranean spotted fever-like illness, Italy. Emerg Infect Dis. 2012;18:702.

56. Estrada-Peña A, Jongejan F. Ticks feeding on humans: a review of records on human-biting Ixodoidea with special reference to pathogen transmission. Exp Appl Acarol. 1999;23:685-715.

\section{Publisher's Note}

Springer Nature remains neutral with regard to jurisdictional claims in published maps and institutional affiliations.
Ready to submit your research? Choose BMC and benefit from:

- fast, convenient online submission

- thorough peer review by experienced researchers in your field

- rapid publication on acceptance

- support for research data, including large and complex data types

- gold Open Access which fosters wider collaboration and increased citations

- maximum visibility for your research: over $100 \mathrm{M}$ website views per year

At BMC, research is always in progress.

Learn more biomedcentral.com/submissions 